\title{
Zorunlu mesleki sorumluluk sigortası
}

\author{
Compulsory professional liability insurance
}

\author{
İbrahim Erdem Esenkaya
}

Anadolu Anonim Türk Sigorta Şirketi, Teftiş Kurulu Başkanlığı, İstanbul

\begin{abstract}
Teknolojik ve sosyal gelişmelere bağlı olarak, insanlık, modern bir dünyaya ulaşmıştır. Bu modern dünya içerisinde yaşadığımız, günlük hayatın ortak özelliklerinden biri de risk ve belirsizliklerle dolu olmasıdır. Risk, sigorta konusunun temel unsurlarından biridir. Tarih boyunca insanoğlu bu riski ortadan kaldırmak ya da azaltmak için mücadele etmiş, bireysel olarak karşılayamadığı kayıpları, paylaşarak azaltmak istemiştir. Bu paylaşma anlayışı, sigorta kavramının temelini oluşturmuştur. Mesleki sorumluluk sigortaları, sigorta kavramı kapsamında "Sorumluluk Sigortaları" alt başlığı içinde vücut bulmuş ve yıllar itibarıyla gelişme göstermiştir.
\end{abstract}

Anahtar sözcükler: risk; sigorta; mesleki sorumluluk sigortası

\section{RISK VE SIGORTA}

Günlük hayat ve gelecek, birçok risk ve belirsizliklerle doludur. Risk, zarar ihtimali veya arzu edilmeyen bir olayın meydana gelme ihtimali olarak belirtilebilir. Kişi bu risklerden endişe duyduğundan bunları ortadan kaldırmayı dener. ${ }^{[1]}$

Belirsizlik, bir olayın sonucunun tahmin edilememesi veya olayın sonucunu etkileyen faktörlerin sonuç üzerindeki genel etkisinin bilinememesi halidir. Her olayı yaratan olumlu ve olumsuz faktörler vardır. Olumlu faktörlerin uygun birleşimi olayı istenen yönde geliştirirken, faktörler birleşiminin istenen yönde olmaması sonucun olumsuz biçimde ortaya çıkmasına yol açacaktır. ${ }^{[2]}$

$\mathrm{Bu}$ her iki kavram sigorta kavramının doğmasına temel teşkil etmiştir. Bu aşamada; sigorta, bir grubun (sigortacı) diğer bir gruba (sigortalı veya poliçe sahibi), sigorta edilende parasal bir kayıp meydana getiren bir şey vuku bulması durumunda toplam bir para ödeme sözü verdiği düzenlemelerdir. Böyle kayıpları ödemek için sorumluluk, poliçe sahibinden sigortacıya transfer edilir. Olay meydana geldiğinde, kayıpların
Due to technological and social developments, humanity has reached a modern World. One of the common features of daily life that we live in this modern World is that it is full of risks and uncertainties. Risk is one of the basic elements of insurance. Throughout history, human beings have struggled to eliminate or reduce this risk and wanted to reduce the losses that they cannot meet individually. This understanding of sharing formed the basis of the concept of insurance. Professional liability insurances are embodied in the "Liability Insurances" subtitle within the scope of the insurance and have improved over the years.

Key words: risk; insurance; professional liability

ödeme yükünü kabullenmeye karşılık olarak sigortacı bir sigorta yapma bedeli talep eder, buna prim denir. ${ }^{[3]}$

Sigorta kavramı temelde hayat ve hayat dışı olmak üzere ikiye ayrılır. Hayat sigortalarının konusu doğrudan doğruya insan hayatıdır. Kişinin hayatta kalması veya ölümü onu fazlası ile ilgilendirir. Bu itibarla hayat sigortaları sınıflandırılırken temin etmiş olduğu hususlar dikkate alınır. ${ }^{[4]}$

Hayat dışı sigortalar; hayat branşı dışında, sigortalının varlığında, çeşitli risklerin sebep olacağı hasarlar ile meydana gelecek kayıpları sigorta teminatı altına almaktadır. Hayat dışı sigortalar sigortacılık terminolojisinde elementer sigortalar olarak isim alır ve genel olarak altı branş altında toplanır:

- Yangin

- Kaza

- Nakliyat

- Mühendislik

- Tarım

- Diğer

- İletişim adresi: Dr. İbrahim Erdem Esenkaya, Anadolu Anonim Türk Sigorta Şirketi, Teftiş Kurulu Başkanlığı, Rüzgarlıbahçe mah. Kavak Sok. No:31, Kavacık, İstanbul Tel: 0553 - 3511251 e-posta: eesenkaya@anadolusigorta.com.tr

- Geliș tarihi: 9 Ekim 2019 Kabul tarihi: 11 Kasım 2019 


\section{MESLEKI SORUMLULUK SIGORTASI}

Mesleki sorumluluk sigortası, hayat dışı sigortalarda diğer branşlar arasında yer alan bir sigorta türüdür. Hukuk toplumsal yaşamın bir ürünü, sorumluluk da hukukun bir ürünüdür. ${ }^{[5]}$

Sorumluluk sigortası, poliçe sahibinin bir hatası ya da ihmali sonucunda diğer kişi ya da firmalarda meydana gelen zararı, kaybı, yasal sorumluluk gereği karşılayan, tazmin eden sigorta türüdür. ${ }^{[6]}$ Mimarlık, muhasebecilik, emlakçılık, hekimlik gibi bir mesleğin icrası sırasında ihmal, hata ya da gereken özenin gösterilmemesi nedeniyle meydana gelen finansal ya da kişisel zararın tazmini için de mesleki sorumluluk sigortaları oluşturulmuştur. ${ }^{[7]}$

İngiltere'de 1980'lerin ortasında yaşanan krizin de etkisiyle mesleki sorumluk sigortalarına talep ve buna bağlı tazminat talebinin keskin bir şekilde arttığı; 1990 'lı yıllara gelindiğinde tıp mesleğine yönelik olarak tazminat talebinin ikiye katlandığı görülmüştür.

\section{HEKIM ZORUNLU MESLEKI SORUMLULUK SIGORTASI}

Ülkemizde hekimler için hekimler için zorunlu mesleki sorumluluk sigortası yapılması zorunluluğu getiren Kanun 30 Ocak 2010 tarih 27478 sayılı Resmi Gazete'de yayımlanmıştır. ${ }^{[8]}$ Buna göre 5947 sayılı Üniversite ve Sağlık Personelinin Tam Gün Çalışmasına ve Bazı Kanunlarda Değişiklik Yapılmasına Dair Kanun'un 8. maddesiyle, hekimler için mesleki sorumluluk sigortası yaptırma zorunluluğu getirilmiştir. Bu madde ile 1219 sayılı Tababet ve Şuabatı Sanatlarının Tarzı İcrasına Dair Kanuna "ek madde 12" eklenmiş ve söz konusu madde yayımından altı ay sonra yürürlüğe girmiştir.

Bu ek maddeye göre; kamu sağlık kurum ve kuruluşlarında çalışan hekimler, diş hekimleri ve tıpta uzmanlık mevzuatına göre uzman olanlar, tıbbi kötü uygulama nedeniyle kendilerinden talep edilebilecek zararlar ile kurumlarınca kendilerine yapılacak rüculara karşı sigorta yaptırmak zorundadırlar. Bu sigorta priminin yarısı kendileri tarafından, diğer yarısı döner sermayesi bulunan kurumlarda döner sermayeden, döner sermayesi bulunmayan kurumlarda kurum bütçelerinden ödenir. Özel sağlık kurum ve kuruluşlarında çalışan veya mesleklerini serbest olarak icra eden hekim, diş hekimi ve tıpta uzmanlık mevzuatına göre uzman olanlar da tıbbi kötü uygulama sebebi ile kişilere verebilecekleri zararlar ile bu sebeple kendilerine yapılacak rücuları karşılamak üzere mesleki malî sorumluluk sigortası yaptırmak zorundadırlar. Zorunlu mesleki malî sorumluluk sigortası, mesleklerini serbest olarak icra edenlerin kendileri, özel sağlık kurum ve kuruluşlarında çalışanlar için ilgili özel sağlık kurum ve kuruluşları tarafından yaptırılır. Özel sağlık kurum ve kuruluşlarında çalışanların sigorta primlerinin yarısı kendileri tarafından, diğer yarısı da istihdam edenlerce ödenir. İstihdam edenlerce ilgili sağlık çalışanı için ödenen sigorta primi, hiçbir isim altında ve hiçbir şekilde çalışanın maaş ve sair malî haklarından kesilemez, buna ilişkin hüküm ihtiva eden sözleşme yapılamaz.

21.07.2010 tarih ve 27648 sayılı Resmi Gazete'de 30 Temmuz 2010 tarihinde yürürlüğe giren Tıbbi Kötü Uygulamaya iliş̧in Zorunlu Mali Sorumluluk Sigortası Genel Şartları, Tarife ve Talimatları yayımlanmıştır. ${ }^{[9]}$ Bu aşamada "tıbbi kötü uygulama" ifadesi "malpractise" ifadesinin Türkçe karşılığı olarak kullanılsa da diğer mesleki sorumluluk sigortalarında örneğin muhasebeciler için "kötü muhasebe uygulaması" ya da noterler için "kötü noter uygulaması" denmemektedir. Kişisel olarak bu ifadenin doğru olmadığını düşündüğüm için çalışma genelinde kanuni tanımlamalar dışında "hekim zorunlu mesleki sorumluluk sigortası" (HZMSS), ifadesi kullanılacaktır.

HZMSS, serbest ya da kamu veya özel sağlık kurum ve kuruluşlarında çalışan hekimler, diş hekimleri ve tıpta uzmanlık mevzuatına göre uzman olanların poliçe kapsamındaki mesleki faaliyeti ifa ederken, sözleşme tarihinden önceki on yıllık dönemdeki veya sözleşme süresi içinde mesleki faaliyeti nedeniyle verdiği zararlara bağlı olarak sözleşme süresi içinde kendisine yapılan tazminat taleplerine, bu taleple bağlantılı yargılama giderleri ile hükmolunacak faize ve sigortalı aleyhine ileri sürülen tazminat talebine ilişkin makul giderlere karşı poliçede belirlenen limitler dâhilinde teminat sağlar. Ancak on yıllık dönemin başlangıcı 30 Temmuz 2009'u geçemez ve bir aydan fazla sigortasız kalınan dönemlerde meydana gelen olaylara bağlı olarak sigortalı dönemlerde yapılan ihbarlar için sigorta koruması yoktur. Poliçe yenilenmez ya da poliçelerin yenilenmesi arasında bir ayı aşan bir süre oluşursa bu döneme gelen tazminat talepleri sigorta şirketi tarafından karşılanmaz. Örneğin; 01.01.2010'dan itibaren yapılan bir HZMSS poliçesinin, 31.12.2018'de bir şekilde yenilenmediğini, 01.06.2019'da ise poliçenin tekrardan yapıldığını farz ettiğimizde; sonradan yapılan poliçe önceki sigortalı yıllara ilişkin korumayı yeniden tesis eder, ancak; sigortasız geçen altı aylık dönem içerisinde yapılmış tıbbi işlemlerden doğacak talepler kapsam dışında bırakılır. Dolayısıyla, sonradan bir mağduriyet yaşanmaması için poliçe yenilemelerindeki bu bir aylık süreye hekimlerimiz tarafından özellikle dikkat edilmesi gerekmektedir.

Sigortalının mesleki faaliyete son vermesi halinde, son sigorta sözleşmesi dönemindeki mesleki faaliyetinden dolayı sözleşmenin bitiş tarihinden iki yıl sonrasına kadar ortaya çıkabilecek talepler de teminat dahilindedir. Yukarıdaki örneğe devam edersek; 01.01.2010 yılında 
yapılan bir HZMSS poliçesinin 31.12.2018 tarihine kadar devam ettiğini ve bu tarihten sonra hekimin mesleğini bıraktığını ve tıbbi faaliyetlerde bulunmadığını farz ettiğimizde; söz konusu hekimin 31.12.2018 ve öncesi dönemde yapmış olduğu tıbbi işlemler ve faaliyetlere bağlı olarak gelebilecek tazminat taleplerine karşı iki yıl daha herhangi bir poliçe olmadan ve ek bir prim ödemeden son poliçe ile koruma sağlanmaktadır.

Hekimlik, ömür boyu icra edilebilen bir meslek olmakla birlikte, bu aşamada hukuken muğlak olsa da idari bakımdan tıbbi mesleki faaliyete son verme üzerinde durmakta fayda görülmektedir. Buna göre; meslek odasından ayrılma (bunun istisnası olarak bazı hekimler mesleki faaliyet yürütmeseler dahi oda aidatlarını ödeyerek üyeliklerini korumayı tercih edebilirler), muayenehane hekimiyse, serbest çalışıyorsa, Ticaret Odası kaydından ayrıma; kamu hekimiyse, SGK provizyon sisteminden ayrılma tıbbi mesleki faaliyete son vermenin bir göstergesi ve idari bakımdan kanıt olarak değerlendirilmektedir. Bununla birlikte tıbbi müdahalelerin yansımalarının uzun süre sonra çıkabildiği dikkate alındığında mesleği bırakma ve iki yıl sonrasında gelebilecek tazminat talepleri hekimler bakımından ciddi bir risk oluşturmaktadır. Buna yönelik olarak mesleğin aktif olarak icra edilmeyen dönemine ilişkin olarak düşük primli bir koruma sağlanması önerilebilir. Bu sorun kamu otoritesi tarafından ele alınarak çözüm üretilmesi gereken bir konu olmakla birlikte mevcut koşullarda ihtiyatılık gereği mesleği bıraktıktan sonra da bir müddet poliçeye devam edilmesinde fayda görülmektedir.

Sigorta sözleşmesi sigortalının tüm mesleki faaliyetini kapsar. Poliçede mesleki faaliyetin yerinin belirtilmemesi veya eksik belirtilmiş olması poliçe kapsamını etkilemez.

Genel Şartların uygulamasında kamu sağlık kurum ve kuruluşları, 5018 sayılı Kamu Mali Yönetimi ve Kontrol Kanununa ${ }^{[10]}$ ekli cetveller kapsamındaki idare, kurum ve kuruluşlar nezdindeki sağılı kuruluşlarını kapsar. Kamu sağlık kurum ve kuruluşları için tümünü kapsayacak tek poliçe düzenlenir. Bu kuruluşlar bünyesinde görevli sigortalının naklen atama, geçici görevlendirme ve sair sebeplerle anılan kuruluşlar içinde mesleğini yürütmesi halinde ilave sözleşme düzenlenmez veya prim talep edilmez. Bu poliçe, kamu sağlık kurum ve kuruluşunda çalışan sigortalının kendi görev yeri ve branşı dışında da olsa ilgili mevzuat çerçevesinde görevlendirildiği yer ve branşlardaki faaliyetlerini de ilave sözleşme düzenlenmeksizin veya prim tahsil edilmeksizin kapsar. Ayrıca, ilgili mevzuat uyarınca, aile hekimlerinin acil sağlık hizmeti sunmak üzere görevlendirilmeleri durumunda sigortalının mevcut poliçesi, söz konusu mesleki faaliyetleri ilave sözleşme düzenlenmeksizin veya prim tahsil edilmeksizin kapsar.
Bu sigorta, sigortalının Türkiye Cumhuriyeti sınırları içinde ifa ettiği mesleki faaliyetleri için geçerlidir. Türk Silahlı Kuvvetlerinin kadrosunda görev yapan sigortalının yurt dışındaki mesleki faaliyetleri teminat kapsamındadır.

Aşağıdaki hâller teminat kapsamı dışındadır:

- Sigortalının, poliçe kapsamında yer alan ve sınırları hukuk kuralları veya etik kurallar ile tespit edilen mesleki faaliyeti dışındaki faaliyetlerinden kaynaklanan tazminat talepleri.

- İnsani görevin yerine getirilmesi hariç, sigortalının, poliçe kapsamındaki kuruluşların sorumluluk alanı dışındaki faaliyetlerinden kaynaklanan tazminat talepleri.

- Idarî ve adlî para cezaları dâhil her tür ceza ve cezai şartlar.

- Ilgili mevzuatla belirlenen çerçevede tıbbi mesleki faaliyet gereği yapılanlar hariç her türlü deneyden kaynaklanan tazminat talepleri.

Sigorta sözleşmesinin konusuna ilişkin olarak sigortalının kendisine tazminat talebinde bulunulduğunu öğrendiği ya da zarar görenin doğrudan doğruya sigortacıya başvurduğu anda riziko gerçekleşmiş sayılır. Dolayısıyla poliçe olay esaslı değil talep esaslıdır. Bu esasta poliçenin her yıl yenileneceği esası hâkimdir. $\mathrm{Bu}$ nedenle yukarıda belirtildiği üzere poliçede boşluk bırakılmadan yenilenerek devam etmesi önem taşımaktadır.

HZMSS poliçesi, yıllar içinde farklı sigorta şirketlerinden düzenletilebilir. Bir tazminat talebi yapıldığında, talebe konu tıbbi işlem geçmiş yıllarda yapılsa bile, tazminat talebinin sigortalı hekime iletildiği tarihte yürürlükte bulunan poliçe üzerinden talep kabul edilir. Tazminat talebine yol açan hatalı işlemin hangi tarihte gerçekleştirildiği dikkate alınmaz. Şöyle ki; sigortalımız poliçesini 2016 yılında A Sigorta Şirketi'nden, 2017 yılında B Sigorta Şirket'inden 2018 yılında C Sigorta Şirket'inden ve 2019 yılında D Sigorta Şirket'inden yaptırdığını farz edelim. 2019 yılında, 2016 yılında yapılan bir tıbbi işlem nedeniyle doğan tazminat talebi sigortalıdan yapıldığında, sigortalı A Sigorta Şirketi'ne değil D Sigorta Şirketi'ne başvurmak ve söz konusu talebi iletmek durumundadır.

Sigorta ettiren, bir tazminat talebi ile karşılaştığında aşağıdaki hususları yerine getirmekle yükümlüdür:

- Haberdar olduğu andan itibaren rizikonun gerçekleştiğini derhal sigortacıya bildirmek,

- Sigortalının sorumluluğunu gerektirecek olayları, on gün içinde, sigortacıya bildirmek, 
- Sigorta sözleşmesi yokmuş gibi, imkânları ölçüsünde zararın önlenmesi, azaltılması ve artmasının önlenmesi için gerekli her türlü önlemi almak ve bu amaçla sigortacı tarafindan verilecek mesleki faaliyet dışındaki sigortacılıkla ilgili makul talimatlara uymak,

- Sigortacının talebi üzerine, olayın ve zararın nedeni ile hangi hâl ve şartlar altında gerçekleştiğinin ve sonuçlarının tespitine; tazminat yükümlülüğü ve miktarı ile rücu hakkının kullanılmasına yarayacak, elde edilmesi mümkün bilgi ve belgeleri makul sürede vermek,

- Zarardan dolayı, dava yolu ile veya başka yollarla bir tazminat talebi karşısında kaldığı veya aleyhine cezai kovuşturmaya geçildiği hâllerde, durumdan sigortacıyı derhal haberdar etmek ve tazminat talebine ve cezai kovuşturmaya ilişkin olarak almış olduğu ihbarname, davetiye ve benzeri tüm belgeleri gecikmeksizin sigortaciya vermek,

- Sigorta konusu ile ilgili başka sigorta sözleşmesi varsa bunları sigortacıya bildirmek.

Sigortacı, zararı önleme, azaltma, artmasına engel olma ve rücu haklarının korunmasına yönelik sigortalının yaptığı makul giderleri, bunlar faydasız kalmış olsalar bile, sigorta tazminatından ayrı olarak tazmin eder.

Sigortacl, sigorta ettirenin istemi üzerine giderlerin karşılanması amacıyla gerekli tutarı avans olarak ödemek zorundadır. Sigorta tazminatı, rizikonun gerçekleşmesini müteakip ve rizikoyla ilgili belgelerin sigortacıya verilmesinden sonra sigortacının edimine ilişkin araştırmaları bitince ve her hâlde rizikonun gerçekleştiğine ilişkin bildirimin yapılmasından kırk beş gün sonra muaccel (vadesi gelen, ödenmesi gereken) olur. Sigortacıya yüklenemeyen bir kusurdan dolayı inceleme gecikmişse süre işlemez.

Araştırmalar, rizikonun gerçekleştiğine ilişkin bildirimin yapılmasından ya da zarar görenin doğrudan sigortacıya başvurmasından başlayarak üç ay içinde tamamlanamamışsa; sigortacı, tazminattan mahsup edilmek üzere, tarafların mutabakatı veya anlaşmazlık hâlinde mahkemece yaptırılacak ön ekspertiz sonucuna göre süratle tespit edilecek hasar miktarının en az yüzde ellisini avans olarak öder.

Dava açılması halinde (idari davalar dâhil), sigortalının ihbarı ile sigortacı takip ve idare etmek üzere davaya her aşamada dahil olur. Sigortalı, sigortacının göstereceği avukata gereken vekâletnameyi vermek zorundadır. Sigortacı dava sonucuna göre yargılama giderlerini ve avukatlık ücretlerini genel hükümler çerçevesinde ödemekle yükümlüdür. Şu kadar ki, hükmolunan tazminat sigorta bedelini geçerse, sigortacı bu masrafları sigorta bedelinin tazminata oranı dâhilinde öder. Günümüzde sigorta şirketleri söz konusu davaları anlaştıkları hukuk büroları aracılığı ile takip etmektedir.

Sigortalı aleyhine cezai kovuşturmaya geçilmesi halinde, sanığın izni ile sigortacı da savunmaya iştirak eder. Bu takdirde, sigortacı yalnız seçtiği avukatın giderlerini öder.

Sigortalının sigortacının onayını almadan yaptığı sulh sözleşmesi, bildirimden itibaren on beş gün içinde onay verilmemişse, sigortacıya karşı geçersizdir; sigortacı haklı olmayan sebeplerle sulhe onay vermekten kaçınamaz. Sigortacı, sulhe bağlı usulüne uygun yapılmış giderleri ödemekle yükümlüdür.

Sigortacı, zarara sebep olan olayın ve zarar miktarının belirlenmesi amacıyla, zarar görenden bilgi isteyebilir. Zarar gören, sağlanması ihtimali bulunan ve istenilmesi haklı görülebilecek ilgili tüm belgeleri sigortacıya vermek zorundadır. Zarar görenin bu zorunluluğa uymaması hâlinde, durumun zarar görene yazılı bildirilmiş olması kaydıyla, sigortacının sorumluluğu, zorunluluk yerine getirilmiş olsaydı ödemek zorunda kalacağı miktarla sınırlıdır.

Sigortacı, ödediği tazminat tutarınca, hukuken sigortalının yerine geçer ki buna halefiyet denir.

Zarar gören, uğradığı zararın sigorta bedeline kadar olan kısmının tazminini, sigorta sözleşmesi için geçerli zamanaşımı süresi içinde kalmak şartıyla, doğrudan sigortacıdan isteyebilir.

Sigorta ettirene; mesleki faaliyetin ifası sırasında sigortalı tarafından kasten sebep olunan her tür olay ile davranışları; sigortalı veya çalıştırdığı kişilerin, poliçe kapsamındaki mesleki faaliyeti ifa ederken alkol, uyuşturucu ya da narkotik maddelerin tesiri altında bulunması sonucunda meydana gelen olaylar; sigortalının talebi üzerine zeyilname yapılması gereken durumlarda sigortalının bu talepte bulunmaması halinde ödenen tazminatın eksik prim oranına denk gelen kısmı rücu edilir.

Sigorta ettiren sözleşmenin yapılması sırasında bildiği veya bilmesi gereken tüm önemli hususları sigortacıya bildirmekle yükümlüdür. Sigortacıya bildirilmeyen, eksik veya yanlış bildirilen hususlar, sözleşmenin değişik şartlarda yapılmasını gerektirecek nitelikte ise önemli kabul edilir.

Sigortacı sigorta ettirene, cevaplaması için sorular içeren bir liste vermişse, sunulan listede yer alan sorular dışında kalan hususlara ilişkin olarak sigorta ettirene hiçbir sorumluluk yüklenemez; meğer ki, sigorta ettiren önemli bir hususu kötü niyetle saklamış olsun. Sigortacı için önemli olan bir husus bildirilmemiş veya 
yanlış bildirilmiş olduğu takdirde, sigortacı on beş gün içinde prim farkı isteyebilir. Önemli hususun sigorta ettirenin kusuru sonucu öğrenilememiş olması veya sigorta ettiren tarafindan önemli sayılmaması durumu değiştirmez.

Sigorta ettiren, sözleşmenin yapılmasından sonra, sigortacının izni olmadan rizikoyu veya mevcut durumu ağırlaştırarak tazminat tutarının artmasını etkileyici davranış ve işlemlerde bulunamaz.

Sigorta ettiren veya onun izniyle başkası, rizikonun gerçekleşme ihtimalini artırıcı veya mevcut durumu ağırlaştırıcı işlemlerde bulunursa yahut sözleşme yapılırken açıkça riziko ağırlaşması olarak kabul edilmiş bulunan hususlardan biri gerçekleşirse derhâl; bu işlemler bilgisi dışında yapılmışsa, bu hususu öğrendiği tarihten itibaren en geç on gün içinde durumu sigortaclya bildirir.

Sigortacı sözleşmenin süresi içinde, rizikonun gerçekleşmesi veya mevcut durumun ağırlaşması ihtimalini ya da sözleşmede riziko ağırlaşması olarak kabul edilebilecek olayların varlığını öğrendiği takdirde prim farkı isteyebilir.

Sigorta sözleşmesi; poliçede tanımlanan mesleki faaliyete son verilmesi, sigortacının iflası, sözleşmenin feshi ve sözleşmeden cayılma hâllerinde son bulur.

Mevzuattan kaynaklanan özel hükümler saklı kalmak kaydıyla sözleşmenin son bulması durumunda işlemeyen günlere ait prim sigorta ettirene iade olunur.

Sigortacının iflası, konkordato ilan etmesi, ilgili sigorta dalına ilişkin ruhsatının iptal edilmesi veya sözleşme yapma yetkisinin kaldırılması gibi hâllerde; sigorta ettiren, bu olguları öğrendiği tarihten itibaren bir ay içinde, teminatsızlığa yol açmayacak şekilde yeni bir poliçe yapmak şartıyla sigorta sözleşmesini feshedebilir.

Sigorta ettiren, aciz hâline düşen veya hakkında yapılan takip sonuçsuz kalan sigortacıdan, taahhüdünün yerine getirileceğine ilişkin teminat isteyebilir. Bu istemden itibaren bir hafta içinde teminat verilmemiş ise sigorta ettiren, teminatsızlığa yol açmayacak şekilde yeni bir sigorta sözleşmesi yaptırabilir.

Sigorta sözleşmesinden doğan bütün istemler, alacağın vadesi gelmiş olduğu tarihten başlayarak iki yıl ve sigorta tazminatına ilişkin istemler her hâlde rizikonun gerçekleştiği tarihten itibaren on yıl geçmekle zamanaşımına uğrar.

16 Mart 2006 tarih ve 26110 sayılı Resmî Gazete'de yayımlanan Mesleki Sorumluluk Sigortası Genel Şartlarına ${ }^{[11]}$ bağlı olarak verilen bu kloz ile sigortacı, sözleşmedeki şartlara tabi olmak kaydı ile sigortalının poliçede konusu belirlenmiş mesleki faaliyeti ifa ederken neden olduğu zarar dolayısıyla ödemek zorunda kaldığı veya kalacağı tazminat tutarları ile kararlaştırılmışsa yargılama giderleri ve avukatlık ücretlerini poliçede yazılı limitler dâhilinde temin eder.

Her tür manevi tazminat talepleri, poliçede belirlenen teminat limitlerinin içinde kalmak ve bu teminat limitinin en fazla \% 50'si ile sınırı olmak kaydıyla teminat kapsamındadır.

Sigortacının, teminat verdiği dönem içinde karşılaştığı tüm taleplerle ilgili sorumluluğu poliçede belirtilen tazminat limitini aşamaz.

Mesleki Sorumluluk Sigortası Genel Şartları'nın "A.3. Teminat Dışında Kalan Haller" maddesinde yer alan düzenlemeler saklı kalmak kaydıyla;

- Ruhsatlı bir sağlık kurum veya kuruluşunda ve acil haller dışında yapılmadığı ve usulünce yetki verilmiş bir anestezi uzmanı gözetimi altında olmadığı sürece, diş hekimleri ve cerrahlar tarafindan genel anestezi uygulanmasından kaynaklanan tazminat talepleri,

- İlk yardım ve acil müdahale hariç olmak üzere, meslekten geçici yasaklanılan dönem içinde verilen her tür tedavi ve sağlık hizmetlerinden kaynaklanan tazminat talepleri,

- Illk yardım veya acil yardım hizmetlerinin sunulduğu yerlerde, yeterli ve gerekli ekipman ile teçhizatın sigortalının kişisel kusuru ile bulundurulmamasından kaynaklanan tazminat talepleri,

- Tıbbi amaçlı kullanım dışında, radyoaktif, zehirli, patlayıcı veya herhangi bir patlayıcı nükleer bileşim veya bunun nükleer bir parçasının tehlikeli özellikleri sebebiyle talep edilen tazminat talepleri,

- Tıbbi amaçlı kullanım dışında, diethylstibesterol (DES), dioxin, urea formaldehyde, asbest, asbestli ürünler veya asbest içeren ürünlerin kullanımından kaynaklanan her tür hastalık (kanser dâhil) veya asbestten kaynaklanan bütün tazminat talepleri

teminat dışındadır.

Manevi tazminata ilişkin düzenleme haricinde Mesleki Sorumluluk Sigortası Genel Şartları'nın "A.4. Aksine Sözleşme Yoksa Teminat Dışında Kalan Haller, Tazminat Talepleri ve Ödemeler" maddesi saklı kalmak kaydıyla ek sözleşme ile teminat altına alınabilecek tazminat talepleri ve ödemeler ${ }^{[11]}$;

- Genetik mühendisliği uygulamalarından kaynaklanan tazminat talepleri,

- Her türlü deney veya araştırmalardan doğan tazminat talepleri,

- Her tür kan bankası faaliyeti neticesinde doğrudan veya dolaylı olarak meydana gelen tazminat talepleri, 
- Tanı veya tedavi amacı olmaksızın yapılan bütün tıbbi müdahaleler ile plastik cerrahların güzelleştirme amaçlı yaptıkları her tür estetik ameliyattan kaynaklanan tazminat talepleri,

- Üremeye yardımcı (kısırlık tedavisi) ya da üremeyi önleyici (kısırlaştırıcı tedavi) her tür sağlık hizmetinden kaynaklanan tazminat talepleri,

- Sigortalının fiillerinden sorumlu olduğu kişilerin kasitlı hareketlerinden kaynaklanabilecek tazminat talepleri,

- AIDS veya onun patojenleri ya da hepatit A, B veya C'ye bağlı olabilecek yahut onlardan kaynaklanan veya onların katkıları ile oluşan her türlü zarar ile bunlar sonucu ortaya çıkan ruhsal rahatsızlıklara bağlı tazminat talepleri,

- İnsan ve hayvan organları, kanları, hücreleri, her türlü ifrazatı, türevleri, genleri, biosentez ve ilgili mamûllerin denenmesi, değiştirilmesi, elde edilmesi, kazanılması, hazırlanması, işlenmesi, elden geçirilmesi, dağıtımı, depolanması, ikame edilmesi, kullanılmasından kaynaklanan tazminat talepleri,

- Sigortalıya, bir sağlık kurumunda yönetici veya işletici olması nedeniyle yöneltilen tazminat talepleridir.

- 21.07.2010 tarih ve 27648 sayılı Resmi Gazete'de yayımlanan Tıbbi Kötü Uygulamaya Ilişkin Zorunlu Mali Sorumluluk Sigortası Tarife ve Talimatı ile HZMSS'nin uygulanmasına ilişkin esaslar belirlenmiştir. ${ }^{[9]}$

Sigortasında her bir olay için azami teminat tutarları aşağıdaki tabloda yer almaktadır. Her durumda sözleşme kapsamında ödenecek tazminat miktarı 1.800.000 TL'yi aşamaz (Tablo 1). ${ }^{12]}$

Teminat tutarı maddi, manevi tazminat ve yargılama giderleri için geçerlidir. Risk gerçekleşmiş olsa dahi, olay başı azami teminat miktarı sözleşme süresi boyunca aynı kalır.

Risk gruplarına göre hazırlanmış olan HZMSS primlerine ilişkin tarife aşağıdadır. ilk kez yapılacak sigortalarda bu prim tutarları uygulanır. Bu prim tutarlarına, acente komisyon bedeli ve üretim giderleri dâhildir (Tablo 2). ${ }^{[13]}$

Prim indirimi ve prim artırımı aşağıdaki tabloda yer alan basamak esasına göre uygulanır (Tablo 3). ${ }^{[13]}$

Bir önceki yıl ya da bir önceki sözleşme süresi içinde herhangi bir ihbar ya da tazminat ödemesi yapılmaması durumunda, sonraki sigorta sözleşmesinde uygulanacak prim indirimi oranı bir üst basamağa göre belirlenir. Eğer bir önceki yıl ya da bir önceki sözleşme süresi içinde tazminat ödenmişse, sonraki sözleşme süresi içinde tazminat ödeme sayısı kadar aşağı basamak tarife uygulanır. Üç ve daha fazla tazminat ödemesi için azami zamlı prim \% 50, üç ya da daha fazla yıl tazminat ödenmemesi durumunda azami indirim \% 20 'dir. Sigorta süresinin bir yıldan kısa olduğu sigorta sözleşmelerinde prim indirimi uygulanmaz.

İlgili mevzuata göre izinli sayılması nedeniyle mesleklerini ifa edemeyen hekim, diş hekimi ve tıpta uzmanlık mevzuatına göre uzman olanların yeniden mesleki faaliyete başlamaları durumunda izinli sayıldıkları anda mevcut poliçelerindeki basamak esas alınır. Sigorta primleri peşin olarak ödenir.

Özel sağlık kurum ve kuruluşları için, sigortalının kurumlar arasında iş değişikliği yapması durumunda, önceki kurum tarafından yaptırılan sigorta sözleşmesinin teminatı devam ediyorsa, yeni kurumun sözleşme süresi sonuna kadar sigorta yaptırma sorumluluğu kalkar. Bu aşamada zeyilname ile yeni sağlık kuruluşunun ismine poliçe üzerinde yer verilmesinde fayda görülmektedir.

Tablo 1. Her bir olay için azami teminat tutarları

\begin{tabular}{cc}
\hline Risk grubu & Azami teminat tutarı $(\mathrm{TL})$ \\
\hline I. Grup & 200.000 \\
II. Grup & 400.000 \\
III. Grup & 600.000 \\
IV. Grup & 800.000
\end{tabular}

Tablo 2. Risk gruplarına göre hazırlanmış prim tutarları

\begin{tabular}{cc}
\hline Risk grubu & Prim miktarı (TL) \\
\hline I. Grup & 150 \\
II. Grup & 300 \\
III. Grup & 500 \\
IV. Grup & 750
\end{tabular}

Tablo 3. İndirim ve prim artırım oranları

\begin{tabular}{ccc}
\hline Basamak & Indirimli prim & Zamlı prim \\
\hline 7 & $\% 20$ & \\
6 & $\% 15$ & \\
5 & $\% 10$ & \\
4 & - & - \\
3 & & $\% 15$ \\
2 & & $\% 30$ \\
1 & & $\% 50$
\end{tabular}


Ayrıca Tablo 1'de görüleceği üzere, 2015 yılından bu yana söz konusu teminatlarda bir değişiklik yapılmadığı dikkate alındığında açılacak bir davada hekimlerimizin teminat konusunda sıkıntı yaşamaması için Sigorta Şirketleri tarafindan düzenlenen "tamamlayıcı hekim mali sorumluluk sigortası" yaptırmaları önerilmektedir.

Hekimler, diş hekimleri ve tıpta uzmanlık mevzuatına göre uzman olanlar için Mesleki Sorumluluk Sigortası Genel Şartlarına göre yaptırılmış ihtiyari sigorta var ise ve bu ihtiyari sigorta zorunlu sigortayla verilen teminatın üstü için yapılmamışsa, bu sigorta ile zorunlu sigorta arasında Türk Ticaret Kanununun birden çok sigorta hükümleri uygulanır.

HZMSS'nin yürürlüğünden önce Mesleki Sorumluluk Sigortası Genel Şartlarına göre yapılmış olan sözleşmeler, taraflar arasında düzenlenecek zeyilname ile zorunlu sigorta hükümlerine uyarlanabilir.

Süresinden önce sona eren sözleşmelerde işlemeyen günlere ait primler, sigorta şirketi tarafından gün esası üzerinden sigorta ettirene iade edilir.

HZMSS'ye dair sözleşmenin yapılması, sona ermesi, risk değişikliği gibi tüm bilgiler sözleşme bazında en geç yirmi dört saat içinde Sigorta Bilgi Merkezine iletilir. iletilen bilgilerin formatı Sigorta Bilgi Merkezi tarafından belirlenir. Gereken altyapıyı kurmamış olan sigorta şirketleri gerekli bilişim altyapısını oluşturana kadar bu sigortayı yapamaz. Sigorta Bilgi Merkezi, sigortasını yaptırmamış olanların tespitini teminen elektronik ortamda Sağlık Bakanlığına erişim sağlar.

HZMSS'ye ilişkin poliçeler tüm sigorta şirketleri tarafindan belirlenen formata göre düzenlenir.

Kamu sağlık kurum ve kuruluşunda görev yapan sigortalının özel sağlık kurum ve kuruluşunda ve/veya mesleğini serbest olarak icra etmesi halinde bu husus poliçe başlangıcında biliniyor ise poliçe kişinin tüm mesleki faaliyetini kapsayacak şekilde düzenlenir. Bu durumda poliçe primi bu Tarife ve Talimat ile belirlenen prime \%35'ten fazla olmamak üzere eklenen tutara göre belirlenir.
Kamu sağlık kurum ve kuruluşlarında görev yapan sigortalının poliçe yürürlükteyken ilgili mevzuata göre özel sağlık kurum ve kuruluşunda ve/veya mesleğini serbest olarak icra etmesi halinde tüm meslek faaliyetini içerecek şekilde tek zeyilname düzenlenir. Bu durumda nihai poliçe primi, bu Tarife ve Talimat ile belirlenen prime $\% 35$ tutarında kalan gün esasına göre ilave edilmek suretiyle belirlenir. Burada hekimin aynı zamanda birden fazla sağlık kuruluşunda çalışması riskin artmasına bağlı olarak ilave prim hesaplanır. Diğer taraftan hekimin birden fazla uzmanlık alanı olduğunda risk grubu hangisinde daha yüksek ise o risk grubuna uygun olarak poliçe düzenlenir. Poliçeye iki uzmanlık dalı girilemediği gibi özel şartlarda da belirtilememektedir.

Uzmanlık öğrencileri (asistanlar) devam ettikleri uzmanlık eğitimleri süresince, eğitimlerini bitirdiklerinde elde edecekleri uzmanlık dalı unvanına göre risk grubuna dâhil edileceklerdir. Örneğin; Ortopedi ve Travmatoloji uzmanlık öğrencisi, uzmanlık eğitimine başladığı andan itibaren Ortopedi ve Travmatoloji uzmanının risk grubu olan "risk grubu 4" ile değerlendirilecektir.

İlgili mevzuat uyarınca, il ve ilçe sağlık müdürlüğü, 112 acil sağlık hizmetleri başhekimliği ve bağlı istasyonları, halk sağlığı müdürlüğü, toplum sağlığı merkezleri ve kamu hastaneleri genel sekreterliklerinde görev yapan hekimler dâhil olmak üzere acil sağlık hizmeti sunmak üzere hastanelerde görevlendirilenlerin (uzmanlık dalı acil tıp olanlar hariç) poliçeleri ilgili risk tablosunda düzenlenen kendi risk gruplarına göre tanzim edilir.

\section{TÜRKIYE’DE PRIM ÜRETIMI ve HASAR ÖDEMESi (Tablo 4) ${ }^{[14]}$}

Görüldüğü üzere yıllar itibarı ile brüt prim üretim artış oranı, brüt ödenen tazminat artış oranının üzerindedir. Illk bakışta bu olumlu gibi görünmekle birlikte, muallak tazminat karşılığı diğer bir ifade ile gerçekleşmiş ve henüz ödenmemiş hasarlardan kaynaklı tazminat

Tablo 4. Branşa yönelik finansal değerler

\begin{tabular}{lcccc}
\hline & $2016-12$ & $2017-12$ & $2018-12$ & $2019-3$ \\
\hline Brüt yazılan primler (TL) & 17.188 .605 & 21.175 .949 & 24.905 .208 & 4.177 .627 \\
Brüt ödenen tazminatlar (TL) & 7.738 .387 & 9.012 .250 & 8.198 .796 & 3.568 .852 \\
Muallak tazminat karşıı̆̆ (TL) & 359.733 .493 & 385.876 .035 & 630.310 .934 & 678.512 .844 \\
Alt branş teminat adetleri & 128.721 & 130.023 & $*$ & 21.092 \\
\hline
\end{tabular}

* TSB tarafından 2018 yılı 12 aylık sonuçlarının resmi internet sitelerine ve resmi portala yüklenmemesi sebebiyle bu döneme ait sektör teminat adet verisine ulaşılamamıştır. ${ }^{[14]}$ 
dikkate alındığında muallak tazminat karlılığının alınan primin 20 ile $25 \mathrm{katı}$ arasında olduğu, bunun da sigorta şirketleri bakımından sürdürülebilir ve kaldırılabilir bir yük olmadığı görülmektedir. Nitekim; kamu otoritesi bu olumsuz tablo karşısında bir havuz oluşturulmuş ve bununla ilgili olarak Tıbbı Kötü Uygulamaya ilişkin Zorunlu Mali Sorumluluk Sigortası Prim ve Hasar Paylaşımı Esasları'nı ${ }^{[15]}$ yayınlanarak HZMSS'ye ilişkin prim ve hasar paylaşımına dair kuralları ayrıca düzenlenmiştir. 1.7.2017 tarihinden itibaren düzenlenen poliçeler kapsam dâhiline alınmıştır. Bu esaslara ilişkin işlemler, Hazine Müsteşarlı̆̆ı, Türkiye Sigorta, Reasürans ve Emeklilik Şirketleri Birliği ile prim ve hasar paylaşım sürecini yönetmekle Görevlendirilen Şirket yetkilisinden oluşan üç kişilik bir "Değerlendirme Komitesi” tarafindan yürütülmektedir.

Dava başlangıç tarihi 2016 - 2017 olan ve 2019 yılında sonuçlanan Yargıtay kararları üzerinde yapılan sınırI incelemede, 20 dosyanın tamamında şikayetçi hasta lehine alt mahkeme kararının bozulduğu görülmüştür. Bu sınırlı incelemede dahi HZMSS'ye bağlı davaların kazanma oranının çok düşük olduğu, dolayısıyla henüz ödenmeyen ve sigorta şirketleri tarafindan karşılık ayrılan tutarların tazminat olarak ödeneceği; yukarıda tabloda belirtilen olumsuz tablonun artarak süreceği anlamına gelmektedir. Bu olumsuz tablonun düzeltilmesi ve sigorta sürecinin sürdürülebilirliğinin sağlanabilmesi için kamu otoritesi tarafından;

- Prim/teminat arasında dengenin sağlanması,

- Sonuçlanan davalara göre poliçe genel şartlarında ve diğer hukuksal konularda gerekli düzenlemelerin yapılması,

- Sigorta ile ilgili ihtisas mahkemeleri kurulması

gerektiği düşünülmektedir.

\section{SONUÇ}

HZMSS, hekimlerimizi tıbbi faaliyetleri kaynaklı karşılaşabilecekleri tazminat taleplerine karşı koruyan faydalı bir sigorta türüdür. Bu sigorta türünün sürdürülebilir olması için prim/teminat dengesinin kamu otoritesi tarafından, ayrıca teminat içeriği ve kapsamının da sonuçlanan mahkeme kararları ve oluşan içtihatlar çerçevesinde tekrardan ele alınmasında ve revize edilmesinde fayda görülmektedir.

\section{KAYNAKLAR}

1. Pekiner K. Sigorta İşletmeciliği (Prensipleri - Hesap Bünyesi). İstanbul: İstanbul Üniversitesi Yayınları; 1981. ss.3-27.

2. Erdoğan i. İsteğe Bağ|ı Sigorta Hizmetlerine Karşı Tutum. İstanbul: Beta Yayıncılık; 1993. s.5.

3. Diacon SR, Carter RL. Success in Insurance, 2 nd ed. London: John Murray; 1988. s.1.

4. Güven O. Açıklamalı Sigorta ve Reasürans Terimleri Sözlüğü, 1. Baskı. İstanbul: Ceyma Matbaacılık; 1995. s.43.

5. "Professional Indemnity and Medical Malpractice" eğitim notları. Swiss Re Academy.

6. Bennett CSC. Insurances of Liability. London: Witherby \& Co. Ltd.; ss.96-9.

7. Smyth C. Insurances of Liability, Foxton, Cambridge: The Burlington Press; 1988. Chap. 14/1, 14/3.

8. Üniversite ve Sağlık Personelinin Tam Gün Çalışmasına ve Bazı Kanunlarda Değişiklik Yapılmasına Dair Kanun. https://www. resmigazete.gov.tr/eskiler/2010/01/20100130.htm

9. Tıbbi Kötü Uygulamaya İlişkin Zorunlu Mali Sorumluluk Sigortasında Kurum Katkısına İlişkin Usul ve Esaslara Dair Tebliğ (2010/1) kapsamında Tıbbi Kötü Uygulamaya ilişkin Zorunlu Mali Sorumluluk Sigortası Genel Şartları, Tarife ve Talimatı. https://www.resmigazete.gov.tr/ eskiler/2010/07/20100721-17-1.htm

10. 5018 sayılı Kamu Mali Yönetimi ve Kontrol Kanunu. http:// www.tki.gov.tr/depo/2017/5018SayiliKamuMaliYonetimive Ko.pdf

11. Mesleki Sorumluluk Sigortası Genel Şartları. https://www. resmigazete.gov.tr/eskiler/2006/03/20060316.htm

12. Tıbbi Kötü Uygulamaya İlişkin Zorunlu Mali Sorumluluk Sigortasında Kurum Katkısına İlişkin Usul Esaslara Dair Tebliğ (2010/1) 'de Değişiklik Yapılmasına Dair Tebliğ. https:// www.resmigazete.gov.tr/eskiler/2015/10/20151028-1.htm

13. Tıbbi Kötü Uygulamaya İlişkin Zorunlu Mali Sorumluluk Sigortasında Kurum Katkısına İlişkin Usul Esaslara Dair Tebliğ (2010/1) 'de Değişiklik Yapılmasına Dair Tebliğ. https:// www.resmigazete.gov.tr/eskiler/2014/07/20140726-9.htm

14. Türkiye Sigorta Birliği İstatistikleri. https://www.tsb.org.tr/ resmi-istatistikler.aspx?pagelD=909

15. Tıbbi Kötü Uygulamaya ilişkin Zorunlu Mali Sorumluluk Sigortası Hakkında Sektör Duyurusu. https://www.tsb.org.tr/ images/Documents/2017-4\%20Sekt\%C3\%B6r\%20Duyurusu. pdf 